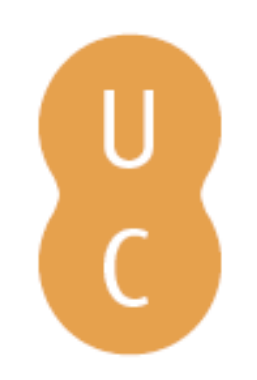

\title{
pompalina
}

\section{Legiões em marcha no tempo de Ovídio}

Autor(es): $\quad$ Varandas, José

Publicado por: Centro de Estudos Clássicos e Humanísticos; Imprensa da Universidade de Coimbra

URL

persistente: URI:http://hdl.handle.net/10316.2/31690

DOI: $\quad$ DOI:http://dx.doi.org/10.14195/978-989-8281-47-0_15

Accessed : $\quad$ 26-Apr-2023 12:37:50

A navegação consulta e descarregamento dos títulos inseridos nas Bibliotecas Digitais UC Digitalis, UC Pombalina e UC Impactum, pressupõem a aceitação plena e sem reservas dos Termos e Condições de Uso destas Bibliotecas Digitais, disponíveis em https://digitalis.uc.pt/pt-pt/termos.

Conforme exposto nos referidos Termos e Condições de Uso, o descarregamento de títulos de acesso restrito requer uma licença válida de autorização devendo o utilizador aceder ao(s) documento(s) a partir de um endereço de IP da instituição detentora da supramencionada licença.

Ao utilizador é apenas permitido o descarregamento para uso pessoal, pelo que o emprego do(s) título(s) descarregado(s) para outro fim, designadamente comercial, carece de autorização do respetivo autor ou editor da obra.

Na medida em que todas as obras da UC Digitalis se encontram protegidas pelo Código do Direito de Autor e Direitos Conexos e demais legislação aplicável, toda a cópia, parcial ou total, deste documento, nos casos em que é legalmente admitida, deverá conter ou fazer-se acompanhar por este aviso.

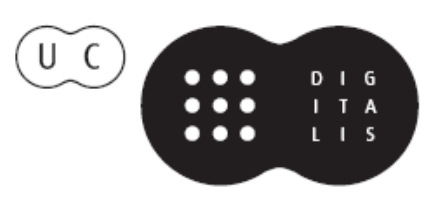




\section{Sociedade, Poder e Cultura no Tempo de Ovídio}

Maria Cristina de Sousa Pimentel e Nuno Simões Rodrigues (Coords.) 


\title{
Legiões em Marcha no Tempo de Ovídio
}

\author{
José VARANDAS \\ Universidade de Lisboa \\ Lembra-te, Romano, é a ti que cabe conquistar \\ os povos.
}

Virgílio, Eneida 6, 851

Ano 9 da nossa Era. Protegida pelas frondosas florestas de Teutoburgo, a infantaria germana aguarda pacientemente as ordens do seu chefe, Armínio, para se lançar sobre as três legiões romanas, formadas em coluna com os seus destacamentos auxiliares e comandadas Por Públio Quintílio Varo. Apanhadas de surpresa, mal dispostas no terreno, e sem capacidade de se reagruparem, as forças romanas, um corpo de exército de perto de 14000 homens (sem contarmos os auxilia) desaparece bruscamente da face da terra. Conta-se que, ao ser informado de tal desastre militar, o imperador Augusto pôs o luto mais rigoroso e, de acordo com Suetónio, durante vários meses foi vítima de acessos de cólera, no meio dos quais gritava: «Varo, devolve-me as minhas legiões!» $\mathrm{E}$ porquê esta raiva? Claro que ninguém, nenhum general, gosta de ver chacinadas as suas tropas, sobretudo em tão grande número, muito menos um imperador romano. Mas seria apenas a derrota e a perda das águias romanas o que tanto apoquentava Augusto? Sem dúvida que sim, a perda dos estandartes de uma legião era algo de impensável para qualquer romano. Implicava um rude golpe na sua dignitas, era um terrível ultraje à suprema divindade - Roma. A sua essência, ao seu estilo de vida. Mas, era mais ainda. A derrota humilhante de Varo e as «reacções» exageradas de Augusto levam-nos a questionar a verdadeira dimensão das forças armadas romanas no contexto do império romano. Seria o exército romano assim tão vital para a estrutura imperial, que a perda de três legiões nos confins da Germânia a pusesse em causa?

\section{As missões do exército romano}

Mas, antes de abordarmos, de um modo mais descritivo, as legiões que se formavam, marchavam e combatiam nos tempos em que Ovídio viveu, e até observarmos o seu contexto evolutivo, convém precisar melhor quais as razões da sua existência. Quais as missões para as quais tinham sido pensadas e criadas.

As legiões de Roma tinham como missão principal e definidora a de fazerem a guerra no exterior. Seguindo um imenso rol de historiadores que, desde o mundo clássico, nos têm apresentado e falado da história militar, o «combate» é o objectivo final dos exércitos. Os soldados têm por dever e por ofício fazer a guerra contra os inimigos externos, sendo a sua missão fundamental

\footnotetext{
${ }^{1}$ Suet., Aug. 23, 4.
} 
o matar esse inimigo, mas sem se deixar matar. É seu dever proteger Roma e os seus cidadãos e habitantes, os seus abastecimentos e tesouros e, não menos importante, os seus templos. Convém, então, que se preparem, formando exércitos e treinando-se, com exercícios e manobras. Devem, também, guarnecer e manter as muralhas e as fortificações e que mantenham, em forma de patrulhas constantes, o inimigo sob observação. $\mathrm{O}$ exército guarda Roma, onde quer que ela esteja representada.

Se a guerra externa - a sua prevenção, preparação e execução - se apresenta como a tarefa principal das legiões imperiais, está-lhe, também, entregue uma outra função secundária: a do policiamento interno. Pelo facto de representar a maior (única) estrutura armada no contexto do Estado, as legiões desempenham outras missões: cabe-lhes a manutenção da ordem no interior das fronteiras e do policiamento das estruturas urbanas. Funcionavam como elemento dissuasor e preventivo de rebeliões e levantamentos, prevenindo muitos factores de conflito. As unidades de stationarii e de burgarii velavam pela segurança das vias e dos mercados. E à marinha cabia o esforço de combater os sempre presentes navios piratas. $\mathrm{Na}$ Judeia romanizada ${ }^{2}$, por exemplo, estabeleceram-se decuriões nas aldeias e centuriões nas cidades e, outros sub-oficiais asseguravam, por todo o Império, a boa ordem e a legitimidade do Estado. Recorria-se ao exército, a este nível disposto em pequenas unidades, para realizar as mais variadas funções repressivas sobre a sociedade. Recorria-se aos stationarii para perseguir, capturar e punir os escravos fugidos e, mais tarde, durante as perseguições aos cristãos, no século III, eram geralmente legionários que as executavam. De resto, e em tempo de paz, cabia ao exército perseguir e eliminar todo o tipo de banditismo, processo difícil, contudo, em tempos de conflito civil, pois aí ambos os lados chamavam ao outro latrones. Finalmente, cabia ao exército a guarda de todo o tipo de prisioneiros, bem como assegurar a escolta de altos dignitários e a segurança de entidades oficiais.

As legiões tinham ainda outro tipo de missões e de tarefas anexas, muitas vezes afastadas da sua actividade principal (a militar) e que não implicavam o uso da força. Para muitos cônsules republicanos e alguns imperadores foram uma tremenda e importantíssima força de trabalho. Representavam mão-deobra qualificada que pouco custava ao Estado. Desta forma o exército romano cumpria, com grande sentido profissional, importantes tarefas administrativas, tomavam conta do cursus publicus, ou seja, transportavam o correio oficial, protegiam as cobranças de impostos e o seu transporte e, em muitos casos, encarregavam-se da execução de importantes obras públicas. Além destas missões objectivas e práticas realçamos ainda o importante estímulo que uma legião representava para a economia e para a cultura, em especial na consolidação do processo de romanização.

\section{Augusto e o nascimento do exército imperial}

É reconhecido que, sob o Principado, Roma conseguiu manter, defender e até expandir o seu império com uma força militar consideravelmente pequena.

\footnotetext{
${ }^{2} M t$ 8, 5-13; Lc 7, 1-10; J., BJ 4, 8 I (442).
} 
O período que decorre entre o estabelecimento no mundo romano de um único poder, o do imperador, que se inicia com Augusto e que se prolonga até Diocleciano, a que se convencionou designar como o «Principado» (27 a.C. a 284 d.C.), é geralmente apontado como o do apogeu do exército romano. O poderio militar apresentado, a sua organização, a sua eficiência e capacidade, só conhecerão paralelo no século XVII da nossa Era. Apesar de sofrerem, ocasionalmente, pesadas derrotas nos campos de batalha, as armas romanas, inexoravelmente, acabavam por vencer as guerras que tinham começado. Certamente que este facto muito deve ao pormenor de este sistema militar se sustentar em soldados profissionais. Os legionários romanos do período imperial possuem uma cultura militar impressionante, estão disponíveis para manterem os mesmos níveis de treino durante os períodos de paz, e encontramse imbuídos de um espírito de serviço a toda a prova. A sua lealdade ao Império é inquestionável. Mantêm-se firmes e disciplinados quer na formatura, quer na marcha, quer, sobretudo, no momento do combate. São leais à sua formação e dependem de um sofisticado sistema logístico e de comunicações. Tudo isto torna-os na mais impressionante «máquina» militar que o mundo conheceu até aos tempos modernos, definindo um modelo que marcaria para sempre a estrutura marcial e organizativa de quaisquer forças armadas dos nossos tempos.

Os exércitos romanos, entre a subida ao poder de Augusto e as profundas reformas de Diocleciano, podem ser seguidos, vislumbrados e reconstituídos em muitos dos seus aspectos mais relevantes a partir de uma enorme quantidade de provas. Textos literários, inscrições, fortes, fortins, acampamentos, campos de batalha escavados na Europa, em África e no continente asiático, artefactos da mais variada ordem associados à presença de legiões, manípulos, coortes e outras unidades, uma imensa iconografia militar que nos chega dos quatro cantos do Império, aparecem como uma torrente sem paralelo. Nenhuma civilização do Mundo Antigo deixou para trás um tal manancial de informação sobre a sua capacidade militar.

Mas como eram? Como se constituíam? Como se equipavam e armavam? Como treinavam e se preparavam? Como marchavam? Como se dispunham no terreno aberto? Como se acantonavam e protegiam? Como se enquadravam em novos contextos geográficos e culturais? Como se estabeleciam nesses novos espaços? Afinal, como lutavam as legiões de Roma no tempo em que Ovídio viveu?

Tudo começa com Octaviano e com o fim da guerra civil que eliminou a república como sistema de governação do mundo dos poderosos Romanos. Chamando-se a si próprio Augusto desde 27 a.C., o filho adoptivo de Gaio Júlio César acaba com o «velho modelo» quando a sua frota de guerra triunfa na batalha de Áccio. Corria o ano 31 a.C. e as legiões romanas irão conhecer uma profunda transformação.

A longa guerra civil tinha tido como consequência, no que diz respeito ao dispositivo militar, um enorme processo de levantamento e recrutamento militar. O ténue equilíbrio político do triunvirato, as antigas querelas de 
César, as ambições políticas de cônsules e procônsules e os velhos inimigos a Ocidente, a Norte e a Oriente, tinham levado a um enorme arrolamento de militares destinados a formar novas legiões que pudessem ser utilizadas nesse destrutivo xadrez político. Por todo o mundo romano as cidades esvaziaramse de homens em idade e situação recrutável, a economia de guerra cresceu exponencialmente. Roma e as províncias transformaram-se em imensos arsenais e campos de treino, as fronteiras desguarneciam-se e ficavam expostas à cobiça dos «velhos» inimigos. A economia civil debilitava-se com as taxações adicionais e com a quebra das rotinas produtivas e comerciais. As legiões multiplicavam-se, exaurindo gerações, debilitando o tesouro e, de certa forma, limitando a progressão da própria estrutura militar.

Áccio introduz um primeiro novo paradigma. $\mathrm{O}$ da redução do número de legiões. Através de desmobilizações, recomposições de unidades e criação de novas unidades, Augusto conseguiu reduzir significativamente o número de legiões em actividade. Das sessenta legiões com capacidade operacional conhecidas no final do triunvirato, a administração imperial cria vinte e sete, que se vêm reduzidas a vinte e quatro (120 000 homens) quando três delas são destruídas por tribos germânicas em 9 a.C. E este número de legiões manterse-á assim até às vinte e nove dos tempos de Vespasiano, às trinta de Trajano e às trinta e três do principado de Severo.

A guerra civil provocou um estado de grande depauperação no que diz respeito a uma demografia masculina recrutável para o serviço militar. A duração dos conflitos (quase um século de actividade militar intensa) impunha um cada vez maior processo de recrutamento sobre regiões cada vez mais fragilizadas, ao qual se acrescentavam factores de pressão não apenas sobre o tradicional sector social de onde saíam os legionários, mas praticamente sobre todos os patamares sociais. $\mathrm{O}$ impacte deste recrutamento maciço sobre as actividades económicas «tradicionais» também deixou as suas marcas. A falta de mão-de-obra em formação em muitos sectores relacionava-se quase em exclusivo com a necessidade de braços para empunhar escudos e gládios.

Ao problema demográfico acrescentava-se um outro, com contornos gravosos. A proliferação da máquina militar romano-republicana produzia uma pressão muito especial sobre as regiões expostas ao conflito directo, com todas as suas consequências, e, também, sobre os espaços onde as legiões se acantonavam. $\mathrm{O}$ estado marcial implicava um controlo directo e total por parte daqueles organismos militares sobre o território e as populações civis nele existentes. $\mathrm{O}$ imenso número de legiões, em vários estados de prontidão, não ajudava à normal aplicação do sistema legislativo (tão importante para o processo económico e social), antes pelo contrário, pulverizava-o, acrescentando um nível de poder, o da legião, sobre o território em questão.

$\mathrm{O}$ excessivo número de legiões e a sua afectação não ao Senado, como seria natural, mas sim a faç̧̃̃es, quebrava a tradicional ligação entre o militar das fileiras e a sua República. Acentuava-se a quebra no sistema de comando, pois surgiam vários. Cada facção comportava-se sobre o território ocupado por outra como uma força de ocupação. De facto o triunvirato produz três 
exércitos romanos diferenciados cuja sustentação, contudo, não é assegurada por novas conquistas territoriais, mas antes pela devastadora utilização dos recursos internos. Além do mais, legiões em excesso impediam um eficaz controlo político por parte das instituições tradicionais do sistema repulicanoromano. Cada facção, e por último o dividido Senado, estavam reféns de uma máquina militar que não parava de crescer, e que para crescer se alimentava do próprio sistema.

A economia de guerra tornava-se insustentável. Todos os recursos se destinavam ao processo militar e, como este não era de cariz expansionista, a despesa nunca poderia ser alocada e compensada por despojos e tributações de guerra impostas a novas regiões. O esforço centrava-se no «velho» sistema produtivo e retributivo.

Augusto entende o problema. Percebe que a manutenção de um grande número de legiões põe em causa a essência do próprio poder de Roma. As legiões, o verdadeiro garante da ordem estabelecida, só o são de facto perante os inimigos do Império, não quando viradas contra si. Politicamente o poder do novo "príncipe» romano continuará a assentar, também, na máquina militar e, por isso, é necessário diminuí-la, reduzi-la a uma expressão que permita ao novo «César» garantir o seu total controlo. A redução das legiões a um número bem mais reduzido torna-se um processo necessário.

Outro aspecto importante na mudança do paradigma militar romano no contexto da solução imperial relaciona-se com o abandono do modelo em que o exército se formava. Em vez de manter (e voltar) ao tradicional sistema militar radicado no modelo do soldado-cidadão (sistema de milícias), que também favorecia, pela sua índole, a proliferação exagerada, Augusto opta por transformar o exército romano numa estrutura profissional ${ }^{3}$. Assim, e porque também passará a funcionar a expensas do Estado, a quantidade de unidades mobilizadas deve ser finita. $\mathrm{O}$ número de legiões é drasticamente reduzido. Esta mudança para um sistema profissional tem muitas vantagens. Um número limitado de legiões permite um melhor planeamento a muitos níveis: concepção estratégica da sua utilização, evolução do seu desempenho táctico, melhor planificação de modelos de treino, melhor preparação dos orçamentos e melhor adequação a um plano político, onde um mais eficaz controlo das províncias surge como objectivo nuclear. Menos homens, mais controlo, menos despesa. Menos legiões permitem reduzir e planear melhor os gastos com o sistema militar. Permitem adequar e institucionalizar um mais eficaz sistema de pagamento ao legionário. A redução permite gerir com mais eficácia o equipamento, permitindo inclusive mais investimento no aperfeiçoamento do armamento/equipamento pesado e ligeiro, ofensivo e defensivo. Possibilita a melhoria dos processos de recrutamento. Os centuriões podem agora escolher melhor os novos recrutas, acrescentando ao processo parâmetros específicos de qualidade. Aumenta exponencialmente a qualidade da formação e do treino individual e das unidades. Soldados, oficiais não comissionados e tribunos

\footnotetext{
${ }^{3}$ Mattern (1999) 81-86.
} 
militares são seleccionados com mais exigência. A isto acresce o facto de a profissionalização se estender por um período de serviço de perto de vinte anos, facto que aumenta muito a estabilidade do sistema militar. $\mathrm{O}$ serviço nas legiões torna-se um «modo de vida» para um número determinado de cidadãos romanos, com regras próprias e um ethos bem definido. $\mathrm{O}$ legionário em serviço vê alguns dos seus direitos serem limitados. Já não é civil e assim a sua cidadania é suspensa durante o «contrato» que tem com a Legião. Também não se pode casar legalmente durante o tempo de cumprimento do serviço militar.

Um número finito de legiões permite sustentar com mais eficácia um estado de prontidão militar. Esta capacidade aumenta os níveis de planeamento sobre operações militares no estrangeiro, ao mesmo tempo que nas províncias se assiste a uma distribuição racional dos efectivos em função dos níveis de insegurança potencial que cada uma apresenta, bem como na tributação que cada uma pode (e deve) assegurar ao dispositivo militar. Outro aspecto de extrema importância, tradicionalmente disruptor da disciplina militar e da ordem, relaciona-se com a passagem à disponibilidade dos veteranos. Um menor número de efectivos permite planear, com mais tempo, através da criação de um fundo para a aquisição de terras, ostensivamente apresentado como saído dos bolsos imperiais, os espaços onde irão ser instalados com as terras que lhes são devidas, bem como preparar os pagamentos de prémios, em numerário, que lhes são devidos por anos e anos de campanhas bem-sucedidas. Formam-se novas colónias por toda a «Itália» e por todo o mundo provincial, permitindo que os veteranos se estabeleçam próximo dos locais onde cumpriram os últimos anos do seu serviço e, com isso, garantindo que as mulheres com quem viveram em concubinato e os filhos que delas tiveram adquiram a cidadania romana.

Augusto, porém, aperta mais a «corrente» que o liga aos militares. Os legionários são pagos por «ele», com moedas que ostentam o retrato do imperador. Os soldados habituam-se a ver o seu imperador, transportam-no na sua bolsa, vêem-no e tocam-lhe sempre que pagam e recebem as apostas quando jogam aos dados. A imagem do imperador torna-se um ícone presencial muito forte. Augusto multiplica-se perante os seus soldados em bustos imperiais, em estátuas de corpo inteiro, em altares nos acampamentos, onde a «nova» divindade imperial se prefigura. As legiões têm presente no espírito e na bolsa a imagem presente do seu patrono - o Imperador.

A lealdade para com o Imperador e com a sua descendência é ampliada com o desenvolvimento (informalmente, no inicio) de um novo culto imperial e com a deificação de todos os membros falecidos daquela linhagem.

Os soldados juntam-se ao exército fazendo um juramento de fidelidade (pessoal) ao Imperador e a Roma. Cada legião ou coorte de auxilia transporta consigo imagens do Imperador nos seus estandartes, acrescentando uma nova simbólica de guerra às «Águias» republicanas. Assumem, ou adquirem, na sua nova postura de profissionais, uma forma específica de demonstrar o seu

\footnotetext{
${ }^{4}$ Varandas (2009) 535-536.
} 
«sentimento» em relação à profissão que desempenham. Por todo o Império epígrafes preservam a memória desses legionários, inscrevendo o nome, a unidade, o posto, as condecorações, os anos de serviço e o ano da morte.

Mas, as mudanças são ainda mais profundas. Veremos, até Diocleciano, os imperadores governarem ostensivamente através das velhas instituições republicanas, envolvendo activamente o grupo senatorial em tarefas relacionadas com o comando militar. Tradicionalmente cabia aos senadores o comando de legiões em campanha (corpos de exército ou legiões isoladas), em parte porque podiam sustentar individualmente as despesas, em parte porque possuíam uma grande experiência administrativa, vital para a organização dos territórios conquistados. Mas esta tradicional ligação, pessoal, à estrutura militar, apresenta-se perigosa para os desígnios imperiais. Afinal de contas é da ordem senatorial que emergem os imperadores. $\mathrm{O}$ caminho da guerra é, também, o caminho para a glória, para a quase deificação. A influência que se adquire pelo facto de se sobressair em combate ou por ter, à frente de legiões, adquirido vastos territórios e imensos tesouros, pode permitir a este «senador-general» ver abertos os «portões» do poder supremo. Não está em causa impedir o bom comando e a distinção no cumprimento do dever militar, desde que essas acções heróicas, sobretudo a vitória alcançada sobre os inimigos seja declarada em nome do Imperador.

Progressivamente o Império irá promover a segunda classe da elite romana, a ordem equestre, para as tarefas da administração militar. Passarão a ocupar cargos de grande responsabilidade, como o futuro comando da guarda pretoriana, unidade de elite destinada a assegurar a protecção exclusiva da família imperial. Gradativamente a classe senatorial vê-se afastada dos cargos proeminentes na estrutura militar. Augusto inicia um processo irreversível de substituição na administração romana, onde grupos menos proeminentes são chamados a ocupar cargos políticos e militares, sensíveis, por todo o Império. A partir da segunda metade do século II, por exemplo, os governadores das novas províncias e os comandantes das novas legiões são já todos praefecti, oriundos do grupo equestre, substituindo os legati, tradicionalmente escolhidos na classe senatorial. A «segunda classe» assume rapidamente o controlo da nova estrutura profissional, quer nas legiões, quer na marinha de guerra. O caminho será o de excluir definitivamente a estrutura senatorial do controlo do aparelho militar. Por volta do século III, os comandos militares e toda a estrutura das legiões estará separada, definitivamente, da administração civil, tanto do ponto de vista legal como, sobretudo, do financeiro.

Estas alterações profundas no sistema de comando das unidades militares permitem a ascensão de uma nova classe de oficiais intermédios provenientes, muitas vezes, das fileiras. Cria-se uma estrutura diferente, agora com oficiais intermédios e superiores profissionais. A legião profissionaliza-se no seu todo, separando-se, em definitivo, do anterior modelo de recrutamento e de organização.

$\mathrm{Na}$ «nova» legião o soldado identifica-se em pleno com a sua unidade e, por extensão, muitas vezes com o contexto regional onde esta está acantonada. 
As legiões recrutam, cada vez com mais intensidade, nas regiões onde se encontram (muitas vezes de forma permanente). O levantamento é levado para lá do espaço itálico e este processo introduz mudanças muito importantes na estrutura da legião e na morfologia do exército romano. Este (o exército romano) é, assim, composto por uma série de «exércitos regionais», que apresentam diferenças interessantes entre si, como por exemplo no sotaque, no jargão empregado, nas diferenças decorativas do seu equipamento e nos diferentes cultos que cada legião pratica.

O exército da antiga república assentava num sistema onde todos os cidadãos de Roma eram obrigados a servir nas legiões durante um certo número de campanhas, que de acordo com o que diz Políbio deviam ser dezasseis. De facto este sistema tinha-se mostrado impraticável com o enorme crescimento territorial. Os soldados não podiam voltar para Itália quando a campanha terminasse para trabalhar nos campos que tinham deixado. No século II, na Hispania, à altura a maior província, e que necessitava de um exército permanente, só eram rendidos ao fim de seis anos, ou mais. A maior parte dos cidadãos servia dez anos nas legiões, situação que para muitas das pequenas e médias explorações rurais romanas se revelou ruinosa. Com o crescimento das guerras civis o modelo de conscrição ${ }^{5}$ tornou-se o mais operativo.

O serviço militar trazia, ainda, um outro problema. As reformas de Gaio Mário, nos finais do século II, introduziram o processo de atribuição de terras aos veteranos que se formavam. Esta recompensa revelou-se a prazo de extrema importância no que dizia respeito à lealdade das legiões. Sendo um direito exigido por todos os veteranos, rapidamente se transformou numa arma política por parte de cônsules e outros legados, que com essa promessa recrutavam e controlavam diversas legiões.

Quando Augusto instalou os seus veteranos, em duas grandes vagas, a primeira em 30 e a segunda em 14 a.C., evitou o que tradicionalmente se fazia: confiscar terras, medida extremamente impopular. Mas esta medida revelou-se muito cara para os cofres do futuro imperador. Díon Cássio escreveu que os veteranos que se reformaram após a batalha contra António e Cleópatra em Áccio foram pagos com os despojos do Egipto 6 .

Provavelmente o elemento financeiro foi decisivo, mas não o único, no processo de redução do exército romano e na mudança da sua estrutura. Os soldados passam a servir dezasseis, depois vinte e no final do século I o tempo de serviço era de vinte e cinco anos. Eram colocados em regime de longa permanência nas províncias, muitas nas periferias do Império, e em retorno

5 Os Imperadores de Roma empregaram sistematicamente a conscrição sempre que necessitaram de forças militares adicionais para a realização de campanhas mais vastas e ambiciosas. BRUnT (1990) 188-214 e MANN (1983) 49-50 desenvolveram perspectivas diferentes sob a utilização do modelo de conscrição. Ambos concordavam que a Roma imperial assentava no recrutamento em voluntários, embora utilizasse a conscrição, em particular no mundo provincial romano e menos no contexto itálico. Brunt argumentava o facto de isso ser normal, ao invés de Mann que considerava o processo muito irregular. $58-86$.

${ }^{6}$ Acerca da concessão de terras aos veteranos por Octaviano/Augusto veja-se KePPIE (1983) 
recebiam um modesto pagamento e praemia, e quando se retiravam ganhavam terras ou uma soma em dinheiro.

Estas condições, sobretudo o serviço militar de longa duração fora do território itálico, desagradaram a muitos recrutas itálicos, o que levou a que bastantes legiões ocidentais fossem compostas por recrutas das províncias, em especial dos territórios ibéricos, de África e da região do Danúbio. A razão era a de que na maior parte das vezes cumpririam serviço nas regiões de origem. Apenas o serviço na guarda pretoriana, com menos tempo de comissão, melhor soldo e a colocação permanente em Itália, continuava a atrair as atenções dos recrutas itálicos.

\section{Combatendo com as legiões de Augusto}

Os legionários em combate deviam cumprir uma premissa fundamental: matar, mas sem se deixarem matar. Parece evidente este conceito, mas de facto a concepção do acto militar e da acção do dispositivo táctico visa em absoluto a aniquilação do inimigo, mas sofrendo um número mínimo de baixas. $\mathrm{O}$ exército romano está concebido (mentalidade que dura até ao século XX) para ir a combate e vencer. Dominar e destruir o inimigo. $\mathrm{O}$ exército existe para ser utilizado e não apenas como uma força dissuasora. Roma não procura a manutenção de um equilíbrio estável e pacífico com as outras potências, ou culturas. As suas legiões são concebidas para combater, para atacar, para adquirir novos espaços e dominar outros sistemas. É um exército concebido, na sua essência, para ser agressivo. Recruta-se, treina-se, equipa-se, desloca-se uma legião (ou um corpo de exército) com um simples objectivo: o de combater.

Possuímos muita informação teórica sobre o combate para o período do Império. Numerosos autores coevos deixaram-nos a sua impressão sobre as conquistas e a manobra das legiões de Roma. Contudo a maioria dessa informação é construída em língua grega e, talvez por isso mesmo, a maioria das descrições das batalhas (matéria sempre muito sensível e muitas vezes proscrita para os historiadores) assume os modelos dos sistemas militares ateniense ou espartano. A «historiografia» coeva segue uma moda ao considerar o facto de o sistema de combate romano não ser diferente, apenas uma adaptação, do que o mundo grego antigo teria inventado. Moda ou erro de perspectiva?

Se observarmos o contexto evolutivo consular/imperial no que diz respeito às condições do combate e do combatente percebemos que o exército romano, nas suas várias formulações, está perante um muito maior número de variáveis, que vão desde a geografia do vastíssimo espaço onde combate, numa longa diacronia, até à tipologia variável do armamento que apresenta.

A arqueologia e outras fontes, como a Coluna de Trajano ou a Coluna de Aurélio, têm trazido à luz uma cada vez maior panóplia de armamento individual característico dos legionários romanos. Consolidando estas informações temos à disposição inúmeras fontes literárias que corroboram muitos dos achados. A informação existente é, no mínimo surpreendente. Parecia que esta infantaria simétrica, especializada, normalizada, devia possuir um equipamento individual 
único. Não é assim. O que surge é uma extraordinária diversidade de armas. O mesmo soldado pode apresentar-se (em momentos diferentes) equipado com quatro maneiras bem distintas. Possui um equipamento de gala, luxuoso, com o qual desfila nos momentos solenes; outro menos ostentatório, mas bem mais eficaz, do qual depende invariavelmente a sua vida, o de combate. Forte, afiado, protegido e bem cuidado; possui, ainda um equipamento (armas e «vestuário») de treino, menos sofisticado e robusto, mas que se usa mais vezes. $\mathrm{O}$ treino ocupa uma parte maioritária na vida do legionário romano. Aqui as armas não são tão afiadas (muitas vezes são em madeira), portanto menos perigosas, pois há que impedir acidentes. E, por último um equipamento imaginado, que dificilmente poderá possuir ou envergar, aquele que manda gravar na pedra da sua sepultura e que, muitas vezes, reproduz armas e armaduras exógenas, onde o paradigma do herói grego surge como motivo principal. Pretendia, o legionário, deixar para a posteridade a imagem do que tinha sido a sua vida, de preferência em "glória».

Acrescenta-se ainda o facto de o armamento individual lhe pertencer. É responsável por ele e deve conservar nas melhores condições toda essa panóplia. Mas o equipamento está de facto com ele? Em combate, sim. No acampamento sabemos que existem depósitos onde as mais variadas armas, munições e restante equipamento se encontram guardadas. Mas serão as armas efectivas do legionário? Ou estes principia, situados sempre na zona central do acampamento, funcionam apenas como local onde o legionário substitui a arma e o equipamento danificado por material novo?

Certo é que, ao seguirmos os autores antigos, como Flávio Josefo, percebemos que grande parte da vantagem táctica do exército romano tinha a ver com a superioridade do seu armamento, muitas vezes, até, em detrimento da sua capacidade táctica de manobra ou da concepção estratégica de toda a operação.

De uma forma geral o exército romano apresenta um modelo padrão de armamento individual ofensivo e defensivo. No período que nos interessa, o infante protege-se com um capacete (geralmente de tipo gálico), com protecção lateral e de nuca. Peito, costas e flancos são protegidos por uma loriga, de tipologia variada (hamata, squamata, segmentata e uma couraça «musculada» de tipo grego, reservada aos oficiais e que reproduz o peito musculado masculino, por vezes bastante decorada com motivos excisos). Cobrindo-lhe um dos lados do corpo, o esquerdo, o legionário imperial apresenta um scutum de forma rectangular, de origem gaulesa (plano) ou samnita (abaulado) e tendo um forte umbo no centro. $\mathrm{O}$ seu fabrico era idêntico aos modelos anteriores, sendo as arestas reforçadas com couro costurado na madeira. Estes escudos eram altamente decorados, provavelmente com motivos identificadores das suas unidades. Nos pés e com vários formatos, de acordo com o terreno e o clima, o legionário calçava umas fortes sandálias (caligae) revestidas na sola por tachas antiderrapantes.

\footnotetext{
${ }^{7}$ Vejam-se a este respeito as dúvidas levantadas por Robinson (1975) 9.
} 
Os soldados combatiam em linha, separados por cerca $1,20 \mathrm{~m}$. Tinham consigo uma lança ( asta) forte e grossa, usada para combater a pequena distância. Tinham também um ou mais dardos de arremesso curtos (pilum) com um formato particular que impedia que o inimigo os pudesse reutilizar. No corpo-a-corpo usavam um gládio relativamente curto, preferencialmente o modelo hispânico e, da sua cintura, pendia ainda um punhal robusto.

Mas o que mais caracteriza o legionário romano em combate é a associação pilum-gladius. Estas duas armas corporizavam a dinâmica inicial e final do engajamento com o inimigo. Assim, inicialmente, arremessavam os pila (dardos), procurando desfazer as primeiras linhas inimigas. De seguida puxavam das espadas (gladius hispaniensis) e, protegendo-se atrás dos escudos, carregavam sobre o inimigo usando aquela arma pequena e afiada de uma forma terrível, geralmente sobre o baixo-ventre do inimigo, rasgando-o, neutralizando-o por completo. Quando os soldados da primeira fila caíam, os da segunda preenchiam o seu lugar.

Um aspecto interessante no conjunto das reformas e das adaptações que após Áccio, progressivamente, vão sendo introduzidas no exército romano, é a forma como a cavalaria vai ganhando presença e importância no dispositivo militar. Irá, ainda, durante muito tempo estar confinada fundamentalmente às forças auxiliares, mas a sua presença, a Oriente e a Ocidente é cada vez mais indispensável. O exército romano, as suas legiões, são de infantaria. Infantaria pesada, organizada em função das suas capacidades de combate, de treino, de armamento e de veterania. Soldados que andam a pé, percorrem o Império formados em colunas, dormindo em acampamentos de marcha fortificados, que constroem e desmontam com as próprias mãos. Apesar de muito se ir dizendo sobre a crescente importância da cavalaria, certo é que a infantaria será (e para mim sempre o foi) a «rainha» do campo de batalha. A campanha, o orçamento, a deslocação, a manobra, o engajamento, até o comando - todos estes aspectos são pensados, formados e desenvolvidos para a legião que combate sobre os seus próprios pés. Contudo, nos tempos em que o imperador Caracala governava, pelos inícios do século III, observamos os estatutos jurídicos dos dois tipos de força militar a aproximarem-se. Infantaria e Cavalaria, modos diferentes de pensar e de fazer a guerra, aproximam-se e complementam-se. As armas individuais, capacetes e couraças seguem esta aproximação, já que tendem a uniformizar-se nos dois ramos. Mas, nesse mesmo tempo, autores romanos continuam a caracterizar o Ocidente e o Oriente como espaços diferentes e opostos até nas armas que empregam. Herodiano é um dos que define os ocidentais como guerreiros de infantaria, armados de espada e de lança, opondo-os aos orientais, os Partos, soldados de cavalaria e arqueiros ${ }^{8}$.

Os exércitos romanos sempre foram considerados como o paradigma da excelência militar. Mas o que levou a que gerações de militares, nos séculos que se seguiram à desagregação do sistema imperial romano, se mantivessem consensuais sobre as capacidades das legiões romanas? A sua capacidade de

\footnotetext{
${ }^{8}$ Herod. 4, 10, 3 e 14, 3.
} 
combate? O dispositivo táctico? O seu pensamento estratégico? A formidável disciplina? A eficientíssima administração militar? O espírito de corpo?

Estes aspectos são todos eles relevantes. $\mathrm{E}$ a sua combinação torna de facto as legiões romanas numa formidável máquina de combate capaz de influenciar a mente de extraordinários generais mais próximos de nós, como Napoleão ou Rommel. Mas o que está na base desta excelência, já que nem mesmo os Romanos nascem ensinados?

Políbio costumava afirmar que «os generais romanos queriam homens que ficassem firmes no terreno quando em inferioridade numérica e sobre grande pressão, e que morressem nos seus postos», se tal fosse necessário. Garantida esta firmeza, prevenia: «...é inevitável que todas as guerras que os Romanos empreendem terminem com brilhante êxito».

Mas como se consegue esta impassibilidade perante a morte iminente? Através do treino. Do intenso, prolongado, cansativo e condicionador treino, da sequência metódica, repetitiva de exercícios e de procedimentos, cada vez mais complexos. A excelência das legiões adquiria-se nos poeirentos campos de exercícios, nas longas e fatigantes marchas, nas repetições infindáveis dos desdobramentos de manípulos e de coortes em manobras ofensivas e defensivas. A máquina militar romana sustenta-se na filosofia de um intenso sistema de treino. É o que faz o historiador Flávio Josefo afirmar que «... os exercícios militares romanos eram batalhas sem sangue e as suas batalhas exercícios sangrentos».

$\mathrm{O}$ processo de treino e a filosofia em que este assenta revelam-se nucleares na constituição de uma força militar de grande eficácia. Embora não seja um aspecto específico das reformas que Augusto introduz no sistema militar, pois já estava bem implantado na formação dos exércitos consulares, continua a ser vital para o novo modelo imperial. Em particular a forma como os Romanos encaram a sua necessidade. $O$ sistema de treino romano não contempla apenas o adestramento dos recrutas ao armamento ou a mera formação básica. A filosofia militar romana pressupõe um processo de treino contínuo, em tempo de guerra, mas, sobretudo, em tempo de paz. Isto permite que as forças romanas, onde quer que se encontrem, e em qualquer estação do ano, estejam num estado de prontidão total. Esta capacidade torna-se muito necessária no contexto das reformas imperiais, sobretudo no que diz respeito ao número de legiões dispostas no terreno. Essa menor quantidade de efectivos «obriga» a que o dispositivo seja mais eficaz e capaz de uma maior (e mais rápida) reacção.

Além do treino básico, os oficiais romanos executam inspecções constantes e rigorosas ao estado de prontidão das suas unidades. Obrigam as legiões a executar manobras defensivas e ofensivas, a manterem-se preparadas para deslocações a qualquer momento, e este processo é aumentado com a prática constante de exercícios envolvendo vários grupos de combate, compostos por várias legiões. A intensidade de um treino rigoroso, estabelecido sob um verdadeiro «manual» operacional, permite manter o legionário afastado dos «perigos» nascidos na inactividade: a letargia, a indisciplina, o amolecimento 
físico, que levam à perda do espírito de combatividade e à diminuição da moral dos soldados. Esta letargia, fatal para os exércitos, é impedida pela maneira como centuriões, decuriões e outros oficiais submetem os seus subordinados a programas intensivos de treino. Desde a simples remoção de terras de um lado para outro, às manobras mais exigentes e sofisticadas, a legião não pára.

O segredo do sucesso do exército romano é o seu treino, que deve ser tão feroz quanto a guerra real. Deve apontar para uma preparação que garanta a primeira missão de uma unidade de combate: matar, sem se deixar matar. A insistência deve privilegiar não apenas o desenvolvimento das capacidades físicas, com e sem armas, mas, sobretudo, alcançar um patamar de obediência absoluta dos homens e dos oficiais. A obediência radica num processo disciplinar violento: Roma introduz e desenvolve como mais nenhuma sociedade humana o fez um processo profissional, homogéneo e consequente onde a uma extrema dureza dos treinos é associado um condicionamento psicológico inabalável, expresso em múltiplos aspectos. A legião não recua. Não se rende, não foge. Um soldado romano não vacila, não contesta, não deserta, não abandona os companheiros. A «alma» do legionário reside na unidade a que pertence, está visível nas «águias» que o precedem na marcha e que nunca, nunca, poderão cair nas mãos do inimigo. Condiciona-se com ordem, firmeza, castigos corporais e a pena de morte. A máquina militar romana institui um modelo de treino e de disciplina que, grosso modo, se manteve inalterável até à Primeira Guerra Mundial, no século XX.

Desde o modelo consular que o exército romano assenta sobre a excelência do treino e a firmeza da disciplina, condições fundamentais que os arrastam para as vitórias sobre inimigos menos treinados e disciplinados. Roma solidificase, também, nas suas tradições militares, num processo que transforma os seus cidadãos numa eficaz, oleada e feroz máquina de guerra. Estas virtudes não se atenuam com a chegada do modelo imperial, antes se acentuam. A profissionalização do exército romano era o passo seguinte. Augusto e os seus sucessores exploraram ao limite a capacidade combativa das suas legiões, a flexibilidade e a capacidade adaptativa aos terrenos, aos momentos e aos inimigos concretos. Treino e disciplina, aliados a tecnologias e tácticas em constante evolução e adaptação, tornaram as legiões romanas, e pelo tempo que duraram, na máquina militar mais eficiente que o planeta alguma vez viu.

\section{Ordem de batalha}

Dispostos sobre o terreno. Firmes, de olhar em frente, impassíveis por fora, determinados em não ceder. Os legionários aguardam as ordens dos seus centuriões a qualquer momento. Disposta está a legião para combater. Vamos vê-la a agir em campo aberto. Em campo aberto os aspectos de ordem técnica podem não ser (não são mesmo) tão determinantes como num contexto de assédio a uma cidade ou a uma fortaleza (matéria que aqui não trataremos). Aqui a simples coragem e o exigente treino suplantam qualquer tipo de material. 
Os autores antigos e a arqueologia dos campos de batalha têm-nos dado relatos e informações interessantes, bem detalhadas, sobre as várias batalhas que as forças do Império travaram ao longo dos séculos. E se, por um lado, a arqueologia de campo ratifica, confirma e desfaz mitos, continuamos a ler com surpresa e interesse alguns dos clássicos literários sobre a arte de atacar ou de suster o assalto do inimigo em campo aberto. Estratégia e táctica nas palavras de Frontino 9 vão definindo a maneira como os Romanos devem actuar no campo de batalha. São inúmeros os conselhos práticos que ali são dados aos futuros chefes militares romanos. Quando em batalha é fundamental provocar o inimigo de forma a que este se esgote, que perca as estribeiras, que faça o que Tibério fez quando «viu as hordas de Panónios marcharem toda a manhã para o combate reteve as suas forças no acampamento, deixando o inimigo exposto às chuvas torrenciais durante todo o dia. $\mathrm{E}$, quando viu que aqueles bárbaros, esgotados pela chuva e pela fadiga, perdiam o ânimo e fraquejavam, ordenou o ataque derrotando-os» ${ }^{10}$.

Definida previamente numa reunião do estado-maior que acompanha o «general» está a maneira como a batalha será preparada. Toda a teoria aprendida e toda a experiência acumulada são aqui empregues no sentido de reduzir ao mínimo os imprevistos de que uma acção daquelas se reveste. $\mathrm{O}$ treino da legião e a disponibilidade dos soldados permite criar sobre o terreno armadilhas e obstáculos que transformem o processo de aproximação do inimigo num verdadeiro inferno. São escavados fossos, espetadas estacas de madeira, bem afiadas, no solo. Depois a legião dispõe-se da maneira tradicional. Agrupa-se em manípulos deixando espaços entre cada quadrado (ou rectângulo), pronta a executar as manobras há muito treinadas. A manobra, o trunfo na manga do pensamento militar romano. A multiplicidade de «figuras» ofensivas e defensivas que a infantaria pode formar num terreno bem escolhido e preparado. Centro e alas completam o dispositivo, mantendo presente, sempre, a possibilidade de se poder flanquear e cercar o inimigo. Esta divisão em três blocos deixa de fora a infantaria ligeira, particularmente fundibulários e arqueiros, deixados à «solta», flagelando de longe o inimigo, desfazendo-lhe as primeiras filas e dispondose à frente, aos lados ou por trás dos manípulos parados ou em manobra. A legião deve estar sempre pronta a atacar o inimigo ou a reagir rapidamente se for atacada.

Desdobrada tacticamente, a estrutura da legião em combate evolui entre o tempo de Júlio César e as reformas de Diocleciano. Nos finais da República e nos primeiros tempos do Império a táctica de César é a que mais se segue. A legião é disposta sobre três linhas que se sucedem

\footnotetext{
${ }^{9}$ Sexto Júlio Frontino (35-104 d.C.). Nasceu, provavelmente, na província romana da Gália Narbonense. Patrício, da gens Júlia, foi pretor urbano (70 d.C.), cônsul (73 d.C.), governador da Britannia (74 d.C.), onde comandou quatro legiões em várias campanhas. Subjugou os Sílures (País de Gales). Regressado a Roma (78 d.C.), escreve o tratado De re militari, que não chegou até nós. É nomeado proconsul Asiae (85-86 d.C.) e escreveu os Strategemata (84-96 a.C.), que aqui nos interessam em particular.

${ }^{10}$ Front., Strat. 1, 5, 1-8.
} 
(triplex acies), modelo que mais tarde evolui (mas não desaparece) para uma estrutura de falange, extraordinariamente compacta, onde os legionários se encostam ombro a ombro e se protegem com os pesados e grandes escudos, transformando-se num forte ouriço carregado de espinhos. Mas, o mais importante não é tanto a existência destes modelos, mas sim a ideia de flexibilidade que estrutura o exército romano. Este, sempre adaptável, dispunha de vários modelos tácticos que podia empregar consoante o terreno, o inimigo e a situação.

$\mathrm{Na}$ base de tudo está, contudo, a legião. Esta é o elemento essencial e matricial de qualquer sistema táctico ou pensamento estratégico. A valência e a excelência em combate das forças de Roma estão na sua estrutura, na sua divisão em coortes, manípulos e centúrias, sempre flexível. Tendo no manípulo a unidade base, onde os soldados agrupados seguem e manobram olhando para o seu signum, a legião pode agrupar-se ou desdobrar-se e, assim disposta, enfrentar qualquer tipo de inimigo, quer ele venha do Oriente, quer esteja no Ocidente. Mas, só entra em combate depois de definir o modelo táctico Flexibilidade, Disciplina e Paciência: eis o «segredo» da legião em combate, nos tempos em que Ovídio viveu.

\section{Os auxilia}

Desde o início do processo expansionista romano, nos tempos da República, que as legiões romanas (afinal de contas apenas compostas por diferentes níveis de infantaria pesada) assimilaram outras unidades, com diferentes armas e desenho táctico, à sua manobra militar, oriundas fundamentalmente das forças militares dos povos derrotados no campo de batalha.

No contexto imperial, o elemento provincial e regional assume uma importância maior e incorpora uma infinidade de tradições culturais militares que a estrutura das legiões irá aproveitar.É sintomático que em todos os exércitos da Antiguidade formados por infantaria pesada se assista à necessidade de lhe incorporar corpos auxiliares com objectivos e processos tácticos bem definidos. O mundo romano incorpora bem estas «especializações». É comum as alas das legiões serem protegidas por unidades de cavalaria armadas com escudo e lança, quer sejam hispânicas, gaulesas ou oriundas da Trácia, ou por esquadrões de cavalaria ligeira vindos do Norte de África ou das terras dos Dálmatas, destinados a servirem como «olhos» da legião, como escaramuçadores ou forrageiros.

Ao peso da legião disposta em combate acrescenta-se a velocidade e agressividade da infantaria ligeira, arqueiros e fundibulários númidas, trácios e sírios e a agilidade das tropas de montanha existentes na Hispânia.

Estas forças auxiliares integravam o modelo militar romano na República, mas a nova mentalidade do Império exigia-lhes «novas competências». A primeira, a da regularidade. As unidades de auxilia assumiam um carácter mais permanente e modelar. A sua presença deixava de ser esporádica. Assumiam-se cada vez mais como membros do exército romano e, 
ao fazerem-no, adaptavam à sua cultura aspectos nucleares da legião. Aumentavam os níveis de disciplina, de espírito de corpo. Os equipamentos e vestuário militar interpenetravam-se e as alas de cavaleiros ou os corpos de arqueiros assimilavam o «design» romano. Existiam, acompanhando a legião, integrando-se no dispositivo estratégico-táctico, de tal forma que a manobra da legião estava muitas vezes dependente de acções concretas levadas a cabo por aquelas unidades.

Os auxiliares passaram a alistar-se, nas unidades com carácter permanente, por um período superior ao do legionário comum. São comuns as referências a vinte e cinco anos de serviço nas fileiras com um salário substancialmente mais baixo e menos regalias. Esta situação durou até ao ano de 212, quando a população livre teve acesso directo à cidadania. Para estas forças o alistamento de longa duração tinha agora a mesma atracção que para o legionário comum. No fim do período, os homens dos auxilia adquiriam o estatuto de cidadãos de Roma, com todas as suas benesses. $\mathrm{O}$ salário é que continuava ainda inferior.

Augusto e os imperadores que lhe sucederam criaram, com carácter permanente, corpos auxiliares de infantaria, cavalaria e unidades mistas. Passou a ser normal que as coortes de auxilia, constituídas por 480 a 800 infantes, se agregassem entre 120 a 200 cavaleiros. Dividiam-se, depois, em centúrias comandadas por um centurião. As forças auxiliares mimetizavam o padrão militar romano, acrescentando-lhe a sua especialização.

O Império distinguia a necessidade de formar «regimentos» compostos apenas por cavalaria, a que chamou alae e organizados em «turmas», comandadas por um decurião. Estas turmas aumentavam a capacidade de manobra e o alcance da legião no terreno.

A presença das forças auxiliares está bem patente no manancial de fontes que nos chegam do período entre Augusto e Diocleciano, partilhando fortes e acampamentos, sendo descritas em marchas e batalhas, representadas nas evidências arqueológicas e nas fontes epigráficas.

Cada regimento ou corpo de infantaria possuía o seu quadro de oficiais, embora muitas vezes enquadrados por oficiais romanos e oficiais não-comissionados (centuriões) romanos. À semelhança do modelo original, estes corpos de auxilia podiam existir com carácter permanente, embora, na maior parte dos casos, fossem recrutados para participar em campanhas específicas e depois desmobilizados. Também, como nas legiões, o nome que tomavam reflectia o do seu criador, ou da região cidade (a Oriente) ou tribo de onde provinham. Outras intitulações relacionavam-se com a sua especialidade militar: lanceiros, arqueiros ou os mais tardios catrafactos. O seu desempenho em batalha (bom ou mau) era proporcionalmente recompensado, reproduzindo quase em todos os aspectos o modelo da legião nuclear através de condecorações individuais e regimentais. Bastantes forças auxiliares foram condecoradas como pia fidelis (leais e fiéis), entre outras distinções que podiam receber, como serem distinguidas com torques. 
Outra forma de recompensar o excelente desempenho militar era através da concessão da cidadania aos militares, ou mesmo a unidades inteiras ${ }^{11}$. Sendo geralmente formadas por não-cidadãos esta era uma distinção muito relevante e ambicionada.

Os auxiliares compunham geralmente as alae de cavalaria, as patrulhas de reconhecimento, as tropas de primeira linha, cuja função era entrar em contacto com o inimigo e flagelá-lo (infantaria ligeira, arqueiros e fundibulários) e, além destas funções no campo de batalha, tiveram, muitas desta unidades, funções relacionadas com o policiamento das várias fronteiras do Império. Por outro lado não se lhe reconhecem grandes capacidades no plano da engenharia militar, embora muitas fossem capazes de construir acampamentos de marcha e até de manusear o trem de artilharia.

No que diz respeito ao equipamento de combate, seja o da cavalaria, seja o da infantaria, era composto pelo modelo tipo do exército romano. Sob o principado encontramos algumas diferenças. O legionário caracterizava-se por transportar consigo o gladius (espada curta) e o pilum (dardo de arremesso), enquanto os combatentes na infantaria auxiliar surgiam equipados com a spatha (espada) e a hasta (lança). Esta diferença, que nos primeiros tempos parece relevante, vai-se esbatendo e, no principado de Trajano, já quase não é detectável. Os homens protegiam-se com protecções metálicas em malha ou em escamas e, com algumas particularidades regionais/culturais, a panóplia do armamento defensivo e ofensivo não se afastava muito do padrão romano. O exército romano e as suas forças auxiliares são dos mais bem equipados do Mundo Antigo, quer no que diz respeito à qualidade e peso das armaduras, quer nas armas que utilizam. Essa qualidade deve-se ao facto de esse tipo de equipamento estar normalizado, ter um excelente controlo de qualidade e ser maciçamente produzido no Império. $\mathrm{O}$ equipamento estava disponível em grandes quantidades e a um preço subsidiado pelo próprio Estado. Também na produção e reparação do mais variado equipamento militar encontramos envolvidas forças auxiliares.

No conjunto do equipamento defensivo, o padrão seguido era o mesmo dos legionários. Os capacetes da infantaria, por exemplo, eram semelhantes aos usados pelas forças de Augusto. Já na cavalaria os modelos são mais variados, mas privilegiando todos a existência de protecção da nuca. Todas as unidades de auxilia estão equipadas com escudos ovais ou rectangulares de grandes dimensões e com reforço central, embora se desconheçam os elementos decorativos. É provável que a latitude decorativa fosse maior para estas formações e que se relacionasse muito particularmente com a sua cultura de origem.

Desde o século I d.C. que os cavalos das alae se apresentam cada vez mais protegidos, levam já ferraduras em ferro e placas do mesmo metal cobrem-lhes o peito,e os cavaleiros recebem escudos maiores e mais ovalados.

\footnotetext{
${ }^{11}$ É o caso de um regimento de cavalaria, recrutado pelo tribuno Petro entre as tribos gaulesas, e que foi condecorado três vezes. Ficou referido para a história como ala Gallorum Petriana milliaria civium Romanorum bis torquata. Petro foi um dos muitos romanos que pessoalmente recrutou e organizou uma ala de cavalaria auxiliar.
} 
O armamento e restante equipamento (e não apenas o de natureza militar) dos auxilia tem sido observado cada vez mais ao pormenor. Diversos trabalhos, sintetizando dados cruciais revelados por uma arqueologia clássica muito activa, demonstram que regulares e auxiliares apresentam modelos e qualidade de equipamento muito aproximada (sandálias, vestuário, cerâmica e, claro, as armas, escudos e elmos), apresentando, contudo, alguma diversidade ${ }^{12}$. É o caso da vasta tipologia de escudos, divididos em várias formas, tamanhos, peso e materiais de construção.

\section{Marchando com as legiões de Augusto}

Formadas, treinadas, prontas para o combate. Assim são e assim devem estar as legiões. Mas como chegam ao local de combate? Como o «escolhem»? Como o preparam? Será o «lugar» onde se mata (ou onde se pode morrer) assim tão importante?

Os teóricos do exército romano, desde sempre, atribuem grande parte do êxito das campanhas que nós conhecemos a dois momentos preparatórios muito importantes: o marchar para o combate e o local onde se defronta, finalmente, o inimigo.

O general, o legado, os tribunos que comandam as forças, são preparados para dar uma importância maior ao local onde as forças devem ser colocadas. O terreno, a orografia, a proximidade de colinas, de rios, de outros obstáculos, deve ser observado com toda a atenção (até modificado, se for necessário), tendo em conta múltiplos factores, entre os quais vias de abastecimento e de retirada, espaço de mobilidade para as alae de cavalaria, disposição, força e características (fortes e fracas) das suas forças e um conhecimento o mais pormenorizado possível das forças inimigas.

Se o conhecimento sobre as suas próprias forças (regulares e auxilia) é da competência do comando operacional, o acesso às condições do terreno e à dimensão, equipamento e moral do inimigo pode não o ser. Apesar de estarmos muito longe do reconhecimento do terreno com meios aéreos ou com imagens em tempo real dadas por satélite, não pensemos que os manípulos romanos, por não terem esse tipo de tecnologia de apoio, descuravam a necessidade de ter informação apriorística e sólida sobre o espaço que pretendiam tomar. Procuravam não marchar ingenuamente sobre o espaço desconhecido. $\mathrm{O}$ exército romano possuía um eficaz sistema de informações, que as recolhia e procurava centralizar em função do teatro de operações pretendido. Para isso usavam-se guarnições, que enviavam patrulhas, compostas por pequenas unidades (cavalaria auxiliar ligeira) e «nativos» romanizados, com bastante regularidade. Dava-se atenção aos viajantes, que com regularidade, iam e vinham dos territórios inimigos, ou mesmo deitando a mão ao menos prosaico processo de espionagem activa sobre o inimigo. Existiam, ainda, unidades militares romanas especializadas na recolha «agressiva» de informações, como os exploratores e os speculatores. Toda a informação recolhida (pelos

\footnotetext{
${ }^{12}$ Entre outros veja-se, Bishop (2006) ou Le Bohec (1989).
} 
diferentes meios) se concentrava ou no consilium do imperador ou nos officia dos governadores provinciais e, a partir destes, nos comandantes de corpos de exército.

Reunida, filtrada e colocada a informação onde ela deve estar, com o corpo militar que deve executar a missão, pode agora o «general» elaborar a estratégia de aproximação. É o momento de despachar as forças para a zona de conflito. Organizada em colunas a legião, ou as legiões, dispõem-se na vanguarda as suas forças auxiliares, em particular a cavalaria. Estas unidades, sobretudo as montadas, têm por missão reconhecer o terreno e o caminho que o grosso da tropa vai percorrer. São unidades bem dimensionadas e equipadas, pois podem ter que combater. Mas não são as mais valiosas, à semelhança da retaguarda, são na «cabeça» do legado mais dispensáveis que as colunas de regulares que marcham no centro do dispositivo enquadrando o trem de bagagens. Este trem, o elemento mais vulnerável e lento da legião, é contudo de grande importância. A sua perda pode representar a desagregação de toda a unidade. Ali vão abastecimentos, sobressalentes e munições (mísseis de arremesso), mas também o cofre de guerra e os bens individuais de cada legionário. Ver o inimigo cair sobre o trem das bagagens poderia desequilibrar a disciplina das colunas. Os legionários largariam os comandos e acorreriam precipitadamente em socorro dos seus pertences. A protecção deste sector é por isso vital e, portanto, extraordinariamente reforçado. $\mathrm{O}$ momento da deslocação é o momento mais frágil no dispositivo de ataque romano, como ficou bem patente na humilhante derrota de Públio Varo em Teutoburgo. Para quem comanda o dispositivo as preocupações centram-se em dois vectores fundamentais: a segurança das bagagens e a velocidade de deslocação. Os estrategos romanos sempre se debruçaram com especial atenção sobre este pormenor da acção militar. Durante a marcha qual a melhor maneira para dispor a infantaria, os auxilia, a cavalaria e, acima de tudo, as bagagens?

Exército romano. Nunca foi um bando desorganizado de indivíduos armados. Quando o observamos, seja nos textos literários, seja nos restos que deixaram nos campos de batalha, percebe-se que era um agrupamento preciso e disciplinado. Cada unidade ocupava com precisão o seu espaço. Para cada corpo de exército, legião, coorte, manípulo, centúria, contubérnia, havia um espaço e uma missão efectiva, a cumprir. Nada nesta máquina militar é deixado ao acaso. Treino, equipamento, marcha, combate, tudo é preparado, visto, analisado, programado com precisão. É um corpo vivo e saudável e, se o vemos muitas vezes inspirar-se em modelos dos inimigos (os gregos em particular) não podemos deixar de pôr em evidência o facto de os Romanos possuírem uma ciência militar.

As legiões no tempo de Augusto continuam e imprimem mais fundo a essência do exército profissional paradigmático, uma tremenda colaboração entre «tecidos sociais» baseada na disciplina. $\mathrm{O}$ exército divide-se em duas massas, uma mais pequena, a dos oficiais e dos oficiais não-comissionados, a outra, imensa, composta por soldados em vários estádios de preparação. Mas é uma divisão simbiótica. Aos primeiros cabe comandar (e, portanto, saber), 
aos segundos importa obedecer. Não é este sistema tão parecido com o dos exércitos actuais?

As legiões são um elemento vital na estratégia de alargamento do Império. $\mathrm{O}$ poder de Roma reside na sua imagem. No impacte que consegue provocar e manter sobre o Outro. O controlo dessa imagem é vital. Afinal, com Augusto, o exército romano é demasiado pequeno para suster invasões em larga escala e o mesmo se passa com as estruturas defensivas de fronteira. Certo é que a possibilidade de invasões em larga escala a Ocidente e a Oriente não se verificou. Incapacidade das forças não romanas? Deficiência dos seus modelos militares? Ou o receio da máquina militar romana? $\mathrm{O}$ medo que as forças romanas causavam, a vasta lista de vitórias, desde a República, quase sempre com muito menos forças, levavam a que o primeiro elemento inibidor sobre os bárbaros fosse a imagem da legião e o medo que ela causava.

E, assim, do Setentrião ao Meridião, depois do choque das armas, quase sempre se ouvia: Roma Victrix! 